\title{
The National and the Popular
}

\author{
Richard Peña \\ Film and Media Studies, Columbia University, NYC, NY, USA \\ rap4@columbia.edu
}

\begin{abstract}
The national and the popular have been an intertwined and ever-thorny topic of the relationship in cinema. So what is "national cinema?" How can national character be expressed in the cinema? When looking at, for example, the history of Brazilian cinema critics rarely felt the need to the question of what constituted a "Brazilian" film; perhaps, it seemed obvious, not worth discussing. As in so many cultures in Asia, Africa and Latin America, the cinema began as something imported for many decades, something brought to the country by foreigners. Turkey also has its own problematic relationship to colonialism: the encounter with the West is not the imposition of something external, but the liberation of something that was always internal. In Chinese culture, the cinema itself was seen as a modernizing element with far less historical baggage than any of the traditional artistic disciplines.

The term popular, as in popular cinema, has its true force, perhaps, in its blurred contours and cultural contradictions; in the supposed opposition of two paradigms, one based on the market, the other drawn from anthropology. One can define the popular simply by focusing on the commercial success of individual works or by studying those things that claim for themselves or are claimed to be expressions of the thoughts, values and the feelings of the "people," however defined. Many of the formulations of popular cinema, however construed, often imagine it as a kind of alternative practice to some kind of other, official or better produced cinemapopular cinema as oppositional cinema. The films offered a free zone, a space in which "official" or promoted values could be questioned or even refused. Yet in the end, they truly do not dislodge that imposed modernization; instead, they offer examples of how one can accommodate oneself to it.
\end{abstract}




\section{Keywords}

national cinema - popular cinema - Brazil - Turkey

The national and the popular have been an intertwined and ever-thorny topic of the relationship in cinema. As with so much nowadays, my meditation on this subject comes out of my experiences as a teacher of film studies. Over the past few years, among my students and even among a generation of younger critics - younger from my perspective, say about 40-I have noticed that there has been a disparagement of the notion of the "national" in discussions and even the programming of cinema. My education in cinema, such as it was, was definitely formed by the idea of the national, or at worst the regional, in cinema. First discovering Latin American cinema in the early 1970s, I was swept up by the arguments of Latin American cinema as an alternative film practice, one that was or at least could be derived from specific historical, political, and cultural traditions from those nations, as well a practice of resistance to perceived Hollywood hegemony. I later discovered that this tendency in Latin American cinema was mirrored in parallel arguments made by African and Chinese filmmakers and critics about their respective cinemas. Being invented in the Sixties - at the start of the post-colonial era-African filmmakers sought to create their own "African" approach to filmmaking, one based on the rich oral traditions of so many African cultures. In China, the attempt was to "sinify" the cinema, to create a "Chinese" film language or approach, a tendency often built around approaches to translate the stylization of what we call 'Chinese Opera,' but they simply call Chinese theater, a practice that includes music, movement, dance, acrobatics, singing and even recitation, into cinematic terms. One can trace these attempts in the work of filmmakers from the People's Republic, such as Xie Jin's masterful Two Stage Sisters as well as from Hong Kong, such as King Hu's martial arts epics that were being made simultaneously.

Yet by the twenty-first century, the notion of a film's national character or identity had begun to appear for many students and critics frankly "quaint,' an old fashioned construction that makes little sense in our digital world without boundaries or frontiers. National film weeks, a staple for so many years of film programming, has been increasingly replaced by personality-based series-director or actor, generally — or by new genre groupings such as LGBT, diaspora, or human rights films.

My other academic experience has to do with those annoying "student evaluations" that American universities insist students fill out each year. One class 
that I generally teach every spring is Cinema History IV: After 1990, the last part of our department's cinema history cycle. Reading over the evaluations last year, I noticed how many students suggested that we add some more "popular" films to the course. I took that to mean films that they had actually heard of or even seen; my menu of figures such as Haneke, von Trier, Kiarostami and Catherine Breillat seemed for them in its way too rarified. After all, if one is teaching a course essentially on contemporary cinema, shouldn't there be some attention paid to those films that have achieved some kind of connection to audiences around the world? So this year I added Jurassic Park to my list-a film I've always liked anyway — and was delighted at how enthusiastically it was received by my class. Generally, students are waiting to hear what I think about our films mean; with Jurassic Park, they were bursting to tell me what they thought about the film. Jurassic Park was not simply much more successful commercially than our other films; for my students, it seemed almost like it belonged to a different artistic medium.

So what is "national cinema?" How can national character be expressed in the cinema? Clearly, here we are trying problematize the whole notion of the national as related to cinema, yet it's revealing, when looking at, for example, the history of Brazilian cinema how rarely critics felt the need to discuss what exactly the "national character" of a film might be. Perhaps for them the question of what constituted a "Brazilian" film simply seemed obvious, not worth discussing. Thus, perhaps one way of beginning this discussion of the national in cinema, at least in the case of Brazil, would be to try to unearth what the early historians of that cinema meant by the national.

If we look at some of the earliest writings on cinema in Brazil, we can see that their authors seem to regard the "national" and the "foreign" interchangeably. Being a "national" film was simply an indication of where was from; there was no clear opposition to its supposed foreign "other." This begins to change around 1910, when the first major waves of imported films, principally at first from France and Italy, begin to dominate Brazilian screens. Increasingly, films made in Brazil- "national" films - were compared unfavorably to foreign films. "Brazilian" almost comes to mean what it is not. As in so many cultures in Asia, Africa and Latin America, the cinema began and to an extent remained something imported for many decades, something brought to the country by foreigners, something foreign that the locals could imitate but rarely if ever equal.

As simply "Made in Brazil" increasingly became identified with an inferior product, new ideas about the national began to emerge. The films of the Italian-Brazilian filmmaker Paschoal Segreto are praised for "their careful handling of national subjects," assuntos nacionais in Portuguese, which referred to 
his film adaptations of classic Brazilian novels. The film Lost Treasure (Tesouro Perdido), by the great Humberto Mauro, is described as "possessing nationality in its scenes," in Cinearte magazine, a clearly ambiguous remark but one that was actually meant as a positive commentary on the film. Away from the mere fact of production, the "national" became increasingly linked to what was being shown on the screen. By the mid-1930s, in a report prepared for the Ministry of Culture of President Getulio Vargas, the Brazilian cinema is positively praised for "achieving its destiny, revealing our rhythms, our artists, our folklore." Simply put, the national had now become what is "ours," obviously in some kind of contradistinction as to what was not ours, or simply put, theirs.

This focus on the distinction between the "ours" and the "theirs" was perhaps especially pronounced in Brazil and the rest of Latin America because of the overwhelming dominance of their film markets by the US cinema from about 1915 onwards, something I believe did not occur as quickly in Turkey. By 1920, US productions constituted between 80 and 90 per cent of the Brazilian market, a position it continues to enjoy even today, when Brazil is producing well over 100 films a year. Moreover, the rupture between "ours" and "theirs" is so much more difficult in Latin America because its hybrid culture is, after all, at least partially "Western" in its very essence. In several of the Yeşilçam films I've seen, characters make the choice between staying in Turkey or moving to the West, most often it seems Germany. Driving out the "foreigner" in other post-colonial societies was perhaps easier conceptually, because of the cultural/religious/ethnic/racial difference between foreign imperialist-cultural or otherwise - powers and the local inhabitants. In Latin America, that would be denying an essential component in the very make up of the idea of Latin America, a hybrid entity made up of shifting percentages of European, African and Native American cultures. As the Brazilian film critic Paulo Emilio Salles Gomes once wrote, "For us, everything is foreign, because nothing is."

This argument over the national, over the "ours" and the "theirs" can be traced through the entire history of Brazilian cinema, from the silent days until today. Let me just focus on one particularly pointed example of this in the 1950s, the warring conceptions of what might constitute "national" cinema between São Paulo's Vera Cruz Studios and Rio's Atlântida Studios. The postwar period was an economically advantageous time for Brazil: the damage to Europe's economy from World War 2 opened the floodgates for both Brazilian agricultural products and manufactured goods to be exported to Europe and beyond. Feeling that it was time for Brazil to take its rightful place in international culture, a group of São Paulo industrialists in the late Forties bankrolled the creation of Vera Cruz Studios, at the time the biggest and most modern film facility in Latin America. Inviting Alberto Cavalcanti, a Brazilian 
who had been active with both the French avant-garde and the British documentary movement, to assume artistic control of the studio, Vera Cruz tried to create a cinema of "international" caliber, a cinema while shot in Portuguese but which largely made little or no reference to Brazil itself—as if identifying its products as Brazilian would immediately mark them as inferior. However, Vera Cruz wound up being a financial failure, closing its doors in 1954, its only truly successful film curiously its most Brazilian in subject matter-Lima Barreto's O Cangaceiro, a kind of western set in Brazil's arid northeast that was well-received at Cannes. Based far more on the Hollywood western than on the historical fact of the cangaceiros - the cangaceiro (roving bandits) band is shown on horseback, when in reality they usually walked-the film played extremely well in Europe and elsewhere. Sadly, Vera Cruz, already facing bankruptcy, had sold all the international rights for O Cangaceiro to Columbia Pictures, which took home most of the profits. Vera Cruz had certainly raised the technical level of filmmaking in Brazil, but its answer to the "ours" vs. "theirs" question seemed to be to reach for the international, practically denying the national altogether.

Even before Vera Cruz was proposed, a film company in Rio called Atlântida had been developing a kind of carnavalesque musical comedy form called the chanchada. There were many types of chanchadas, but many of the most notable were films that offered parodies and I would argue critiques of the Hollywood cinema that so dominated Brazilian screens. For example, Fred Zinnemann's classic western High Noon is Brazil was released as Matar ou Morrer (Kill or Be Killed). The Brazilian chanchada response was entitled Matar ou Correr (Kill or Run Away). Throughout, chanchadas offer unflattering portraits of Brazil and Brazilians - they are depicted as being weak, cowardly, the opposite of those enterprising, confident Americans. But it is in this very "celebration" of Brazilian underdevelopment that the national emerges; being "underdeveloped" does not mean being inferior, just different, and with that gesture one can feel a Brazilian culture simply refusing to take part in some kind of competition that it's pretty much destined always to lose.

A great example of a kind of counter-argument to the Vera Cruz model was a chanchada from $195^{2}$ that went by the simple name of Carnaval Atlântida, by José Carlos Burle and Carlos Manga. The setting is a film studio, in which a major Hollywood director, "Cecilio B. DeMilho," has set up shop as he prepares to film an epic about Helen of Troy. He is busily casting the film and getting the sets ready, when he has an encounter with two of the studio's janitorial staff, played by Grande Otelo and Cyl Farney. Neither is convinced about the worth of DeMilho's project, and after a brief discussion, the duo shows him how they would imagine the story of Helen of Troy could be told-in Brazil. 
They magically transform the scene into a kind of escola de samba, the queen dances freely with her Afro-Brazilian slaves and her ladies-in-waiting become a chorus line. After a couple of minutes of this joyous chaos, DeMilho screams for them to stop their "imaginary scene" and get back to work.

The meaning is pretty clear. DeMilho wants to impress his audience with production values, gorgeous sets and beautiful women, calling attention to his project's fabrication but not really to the project itself. Grande Otelo and Cyl Farney "carnavalize" the story of Helen of Troy, transforming the scene into a joyous free zone in which gender and racial barriers are at least temporarily lifted. Brazilian cinema, Carnaval Atlântida seems to be saying, can't compete with the US cinema because (a) it simply cannot, lacking its resourses, and (b) because more importantly it doesn't need to. No matter how cheap or silly it looks, it's "ours," not theirs. The question of the national for Brazil, perhaps, is not so much what it is, but what it is not, a tendency applied more generally to the region that can be found in critical Latin American thinking about the politics of identity dating back to the beginning of the twentieth century, in a bevy of writers ranging from José Enrique Rodó, José Martí, or Jose de Vasconcelos.

Thus, the question of the national in Brazil evolved from the site of production to the inclusion of local color in terms of stories, music and settings to finally, in the Sixties, to the attempt to create a Brazilian, or Latin American, or Third World film language, as seen in the work of Cinema Novo filmmakers such as Glauber Rocha. The history of this third phase of the national can also be read alongside the whole advent of "modernism" in the cinema, but again, subject for another discussion.

Turkey also has its own problematic relationship to colonialism. To an extent, it might want to assert that, like Brazil, the west and Western culture are simply an intrinsic part of the Turkish spirit, or as Savaş Arslan defines it, özenti. Following Arslan, özenmek, the verb form related to özenti, "involves a movement that starts at the self, enters another self, and then returns to itself." A relationship between self and others, it implies the need to detour through another in order to truly find the self. In that way, the encounter with the West is not the imposition of something external, but the liberation of something that was always internal, waiting to find the means to be expressed; one can also assume what the implications of this might be for Islamists. Arslan cites the example of Islamist director Yücel Çakmaklı, who rails against a kind of Turkish cinema he calls "cosmopolitan cinema," whose very problem is that is that it is özenti, and thus lacks "essence, purity and originality." For Çakmaklı and those like him, in the process of becoming the Other, something is not liberated but instead is lost or suppressed, leaving not a new hybrid form but just an empty shell. 
Arslan further describes the controversy of over Turkification, a process he defines as "one of the driving motives of a cumulative modernization project of a newly founded nation-state that had multiple repercussions on the social, economic, political, and cultural life of the Republic." Turkification itself comes in two varieties: from "above,' that is as promoted by the Republican authorities in the first decades of the newly-constituted Turkey, where the destiny of Turkey was not to be seen its connection with the "East," and all that entails, but with the West; to accept itself (even if others wouldn't) as part of that political/cultural construct. Turkey's refusal to participate in the Bandung Conference, an event that practically invented the notion of post-colonialism, was indicative of its imagination of itself within the Western sphere.

This Turkification from above is contrasted to what Arslan calls "Turkification from below," in which he claims the films of Yeşilçam played a key role. Although one can certainly point to antecedents and descendants of Yeşilçam, its heyday was certainly from the early 196os to the early 1980s, a period of much upheaval in Turkey brought on by several interventions by the military and other factors. Remarkably, the Turkish cinema of that period has an enormous increase in production at a moment in which most Western cinemas were experiencing severe entrenchment. Dependent almost exclusively on its internal market, the explosion of Yeşilçam corresponded with the enormous growth of the Turkish population, which from 1960 to 1980 practically doubled. This increased urbanization created the conditions for a much expanded audience, for whom cinema remained the primary source of entertainment until the late Seventies.

The films of Yeşilçam continued the discourse of modernization already introduced in various ways by the powers of the republic, but crucially in their own ways. Turkification from above provided examples for how to be modern; Turkification from below was instead about the negotiation with modernity, brought about by the increased urbanization and industrialization of the country, and the subsequent social changes brought on by those forces. They were dramas about what is the national that rejected the didactic thrust of social realism, offering instead not correct behavior but a series of binaries-rural vs. urban, religious vs. secular, Turkish vs. non-Turkish that were through modalities of melodrama.

Again, one might compare the Turkish experience with those of other "problematic" post-colonial cinemas. In the Shanghai-based Chinese cinema of the Thirties and Forties, the cinema itself was seen as a modernizing element of Chinese culture. With far less historical baggage than any of the traditional artistic disciplines, cinema could more freely capture and express modern life and relationships. Its artists developed a filmmaking style that favored long 
takes, mobile cameras and deep spaces: a cinema that invited audiences to see films not merely as texts—composed expressions—-but as openings to the world around them, a world that the spectator would have to learn to negotiate for him or herself. This emphasis of individual consciousness and experience, highlights of modernity, flew in the face of a culture that linguistically has traditionally even had problems rendering the concept of being alone.

An even closer example in the Chinese context would be that of the Cathay Studio films. The great rise and transformation of Hong Kong cinema into a world-class industry in the Fifties was led by two major studios, Shaw Brothers, who pioneered period opera and wuxia (martial arts films), and M.P. \& G. I, a studio universally known as Cathay. Its founder and chief executive, Loke Won Tho, had studied at Oxford and spoke a number of western languages. For Loke, the cinema was the most powerful medium for helping transform Hong Kong (and by extension, China) into a "modern" nation, a modernity that Loke identified exclusively as western. In film after film, Cathay emphasized characters who lived in Western-style houses, dressed exclusively in western clothes, and had modern-identified jobs ranging from airline hostesses to car salesmen; culturally, they show their interest in everything from Western opera to mambo- - even when sung in Chinese. In one of their first great successes, Mambo Girl, starring the irrepressible Grace Cheng, the title character, a free-dancing, popular teenager, learns that she was actually adopted. Distraught at first, she soon realizes that ancestral relations are fundamentally meaningless next to the mechanisms of self-identification; indeed, when the Mambo Girl's real mother appears at the final birthday party, she's actually kept from seeing her daughter, a curious re-working of the myth of Stella Dallas. One could say that Cathay films substitute what we might call a "geo-trope" - a sense of place or setting - for a chrono-trope, a sense of time or period. If asked where do the characters of Cathay films like Mambo Girl live, the correct answer would be "in modernity." Their Chinese-ness seems secondary to their participation in a self-concept that held, correctly or not, to be beyond the national.

The Yeşilçam films I have seen on the contrary seem grounded in the geo-trope of Turkey. Modernity must be negotiated and adapted by characters who will continue to live in a world which at best has only partially accepted its tenets. Indeed, one of the characteristics of Yeşilçam films that interests and frankly delights me is their extraordinary speed. It seems to be not unusual to see a character move from rags to riches to back again in the space of a single reel, i.e. 20 minutes. Characters who start as friends become enemies, or simply disappear. The instability of the narrative worlds apparently necessitates some kind of foundation against which the vicissitudes of rapid, uncontrolled (or uncontrollable) changes can be measured. Again, quoting Arslan, Yeşilçam 
produced "an ambivalent set of practices in response to the West, to a western medium offering the possibility of a realistic representation of the world."

The term popular, as in popular cinema, has always been enormously elusive to define. Its true force, perhaps, lay not in its rigid definition but in the way its blurred contours and cultural contradictions may be explored through the supposed opposition of two paradigms, one based on the market, the other drawn from anthropology.

One can define the popular simply by focusing on the commercial success of individual works or by studying those things that claim for themselves or are claimed to be expressions of the thoughts, values and the feelings of the "people," however defined. This opposition can lead to the dichotomy of seeing popular culture simply as "mass culture"-industrially produced for wide-scale distribution and consumption vs. "folk culture" - artisanally produced and locally consumed. Neither side of this market/anthropology distinction is simple. One might assume that market approaches would be essentially quantifiable, but so often records have been lost or destroyed, they might be difficult to access or may not be truly reliable. Market records do allow us a kind of information about popular cinema, but what is truly popular in this approach? Is our measure the films that made the most money or those films that were seen by the largest number of people? These are not always the same thing; one film might play in the finest, most expensive cinemas, earning top dollar, while another may languish in secondary if widespread release circuits. This second film may well be seen in the end by more people, but might not the overall impact of the first film-whose impact might move beyond the cinema into journalism, music or fashion-be really the more "popular" of the two? Moreover, market records, such as they exist, rarely count more marginalized audiences, such as military personnel abroad or students shown films in schools. Italian neorealist films, as pointed out by several scholars, were seen by increasingly dwindling audiences after the first few hits such as Roma Citta Aperta or Bicycle Thieves, especially when compared to the swashbuckling movies directed by Ricardo Freda; yet wouldn't the lingering impact of neorealism, even today, count against the box office success of the largely forgotten films of Freda?

Anthropological approaches, moreover, are notoriously hard to apply to the cinema. Whatever else it means, "popular" cinema almost never means films created by "the people" themselves, unlike popular theater, music or painting. Until very recently, most people never had he means, financial or technical, to make their own films; the poor and marginalized could be the subjects of films, but never their producers. One interesting example of this is the case of a Brazilian film, Five Times Favela, a collection of short films released in 1962, all 
shot in Rio's gigantic slums (favela in Portuguese) by white, middle class, politically engaged filmmakers, using many inhabitants of those slums as actors. A few years ago a new version was released, Five Times Favela - This Time by Us, another collection short films shot in the favelas only this time by filmmakers who were also favela inhabitants.

Perhaps one might link cinematic form and storytelling to cultural practices which existed before the cinema which were then adapted by the medium. Europe's long tradition of passion plays-re-enactments of Christ's life, suffering and death-were among the first long form films created in the early days of cinema. As has been shown, quite often the images of scenes from Christ's life were actually themselves re-creations of images found in postcards or other publications. Yet here we run the risk of eliding a culture that is "of the people" which can't be separated from the production of the mass, industrial culture that printed these religious images by the thousands, if not millions. Norwegian film scholar Anne Marit Myrstad has shown how so much of Scandinavian silent cinema was made up of rural folk tales re-packaged for the masses that had abandoned the country for the city at the end of the nineteenth century, a kind of exercise in nostalgia that nevertheless reaffirmed their move to the city. Clearly, it's hard to speak of a pure "folk cinema" in such a complex production context.

At the same time, how can we speak of a popular culture that exists outside of mass, industrial culture; can we really speak of popular cinema without some reference to the market? If it is popular, it has to have been seen, but if it is widely seen, it will have to be mass-produced and distributed. The problem boils down to this: can an artwork, industrially and centrally produced, really be said to express something of "the people?" Or does the market essentially link production that is not of the people with consumption that is? Markets may well influence what gets produced or not produced, but they would seem a crude way to measure actual values and desires.

The work of Michel de Certeau has offered a construct he calls "the production of consumers." His work looks at the differentiation of audiences during the French 1930s, moving away from the monolithic concept of "mass audience" for popular culture and more towards the specific appeals felt by various groups. Yet de Certeau seems to imply that the choices of these culture consumers are free- that is, not shaped by other, outside forces such as advertising or journalism, or that somehow these consumers had some choice in what was being made for them. Can a history of cultural hegemony in popular culture be written without some attention to a counter-history written of resistance to that hegemony.

Are we back at our original assertion: the popular is simply what people like? Of course, then we would need to we ask liked by which people, or how 
many, not to mention who or what determined what would be on offer for them to make a choice in the first place. Any notion of popular cinema would have to confront those complexities and others.

So how then can we ask was Yeşilçam a "popular" cinema. Again, we can examine the question from the points of view of market and anthropology. Yeşilçam, at least until the early Eighties, did extremely well with Turkish audiences - so well that Turkish cinema, from what I have read, regularly surpassed the box office of Hollywood films in Turkey, making Turkish cinema one of the very few examples of a local product that favored by local audiences over the imported object; moreover, unlike the Hong Kong cinema, another local cinema that outperformed Hollywood for many years, Turkish cinema was hardly exported-it was made for and consumed by Turkish audiences. Indeed, the very concept of a popular cinema implies the existence of another strain of filmmaking that was "unpopular," or at least not as popular. For much of the Fifties, Sixties and Seventies, there really was no alternative to Yeşilçam in Turkey-it simply was the Turkish cinema, unlike, for example Bollywood, or Hindi commercial cinema, which always existed alongside regionally produced cinemas in India such as the Bengali or Telegu cinemas that featured work by such distinctive auteurs as Satyajit Ray, Ritwik Ghatak or Govindan Aravindan. Many of the formulations of popular cinema, however construed, often imagine it as a kind of alternative practice to some kind of other, official or better produced cinema-popular cinema as oppositional cinema. Can we still speak of Yeşilçam as popular cinema when in fact it simply was Turkish cinema, with for decades no real competition?

As mentioned earlier, notions of popular cinema sometimes try to link it to cultural practices or discourses that pre-date the cinema, such as in the case on the European "passion play" films based on the life of Christ, or again the use of mythological tales and iconography throughout Indian cinema. Was there a similar incorporation of older, traditional Turkish cultural forms into the cinema of Yeşilçam? Perhaps a parallel might be made around the incorporation of arabesk, which Arslan defines as "deemed to be like Arab cultural forms - the word "deemed" is interesting here, as it implies a disputed parentage. Elements of arabesk culture soared in Turkey especially after the widespread popularity of Egyptian cinema, especially during its "golden age" of the Forties and early Fifties. Arabesk culture was frowned upon by the Republican authorities, seeing it as an unwelcome influence from the East, while embraced especially by the migrants beginning to flood urban centers. But perversely, it would seem that the "resistance culture" being embraced by the masses was again itself something largely imported, a nostalgic throwback perhaps to the memory of Ottoman glory in the mélange of cultures that constituted the Empire. The 
question might be whether this support of the arabesk signaled a true allegiance or interest to local eastern cultures, or whether it primarily represented that which was frowned upon by the Republican authorities.

There were far too many Yeşilçam films made to offer a simple claim as to whether or not they were resistant or compliant, conformist or subversive, to Kemalist republican values. Just as with Hollywood films, one can find examples that will support practically any possible political reading of them as progressive or reactionary, depending on your point of view and mode of analysis. Yet what I have seen of Yeşilçam reminds me perhaps somewhat of the spirit of the Brazilian chanchada sequence we saw before. The films offered a free zone, a space in which "official" or promoted values could be questioned or even refused. They allowed audiences a temporary respite from the pressures of an imposed modernization that often ran up against centuries old lifestyles, beliefs and cultural practices. Yet in the end, they truly do not dislodge that imposed modernization; instead, they offer examples of how one can accommodate oneself to it. Again, quoting Arslan, "Though they-the Yeşilçam filmmakers-aimed to tell, or make the cinema tell, things other than what they criticized Yeşilçam for telling, they end up within the same mode of narration." Perhaps the greatest symbol of this is the odd spectacle of dubbing that characterizes so many Yeşilçam films: again and again, the characters' lips are moving, but someone else is doing the talking.

Not speaking or even reading Turkish, and with limited access to especially Yeşilçam films, I can only use my cursory knowledge of these films as a way of refining my thoughts about other national cinemas that I know much better. There is so much of the Yeşilçam experience that relates so essentially to the role cinema has played in cultural and political life, not only in Turkey but throughout the world, and I look forward to reading the work of many of you here. 